\title{
Market Orientation, Government Regulation, Competitive Advantage and Internationalization of SMEs: A Study in Malaysia
}

\author{
Akbar Afsharghasemi ${ }^{1}$, Mohamed Zain ${ }^{2}$, Murali Sambasivan ${ }^{3} \&$ Serene Ng Siew Imm ${ }^{4}$ \\ ${ }^{1}$ Graduate School of Management Universiti Putra Malaysia, 43400 UPM, Serdang, Malaysia \\ ${ }^{2}$ Faculty of Economics and Administration, King Abdulaziz University, 80201, Jeddah 21589, Saudi Arabia \\ ${ }^{3}$ Global Entrepreneurship Research and Innovation Center (GERIC), Universiti Malaysia Kelantan, Persint 15, \\ Putrajaya, Malaysia \\ ${ }^{4}$ Faculty of Economics and Management, Universiti Putra Malaysia, Serdang, 43300 Selangor Malaysia \\ Correspondence: Akbar Afsharghasemi Graduate School of Management Universiti Putra Malaysia, 43400 UPM, \\ Serdang, Malaysia. E-mail: afsharghasemi76@yahoo.com
}

Received: June 1, 2013

Accepted: June 24, 2013

Online Published: June 25, 2013

doi:10.5430/jbar.v2n2p13

URL: http://dx.doi.org/10.5430/jbar.v2n2p13

\begin{abstract}
Small and medium-sized enterprises (SMEs) make remarkable contributions to the economic growth of developing countries. As a newly industrialized country, the Malaysian economy predominantly depends on the SME sector. However, this study seeks to redress this by reporting the key drivers influencing the internationalization process of SMEs such as market orientation, government regulation and competitive advantage on internationalization of manufacturing SMEs in Malaysia. To empirically test those factors, primary data was gathered using the survey questionnaire method. The survey instrument was distributed to all manufacturing SMEs involved in exporting which are located in the Klang Valley of Malaysia and total 257 questionnaires were received (FMM, 2012). The findings indicate the significant role of market orientation, government regulation and competitive advantage in their process of internationalization. Furthermore, the study has added to the body of knowledge by introducing competitive advantage as a mediating variable between market orientation and government regulation with internationalization of manufacturing SMEs in Malaysia. The results of this research could help practitioners and managers of SMEs in the manufacturing sector to be in a better position to improve their internationalization efforts.
\end{abstract}

Keywords: Internationalization of SMEs, Market Orientation, Competitive Advantage, Government Regulation

\section{Introduction}

The degree of prominence when it comes to SMEs in the economic growth of a country has projected them as a pivotal factor within the recent policy making of each and every country. (Ale Ebrahim et al., 2010). The internationalization of SMEs from developing countries and transition economies has drawn an ever- increasing attention within this contemporary era. (Ibeh \& Kasem, 2010). Significantly, manufacturing SMEs are playing an undeniable role in the world markets and Some of the aforementioned SMEs are generating revenues within the international markets which is more than the earning in their domestic market (Chelliah et al., 2010). While many researchers have focused on understanding the influential factors in internationalization of SMEs (Majocchi et al., 2005; Javajgi \& Todd, 2011; Masca, 2012) there is less research addressing the role of the market orientation, competitive advantage and government regulation in the internationalization of SMEs (Mtigwe, 2005; Liu et al., 2011). This study focuses on filling this gap by developing a conceptual framework based on literature review.

The purpose of this research is to extend the literature which addresses the relationship between those influential factors that mentioned and internationalization of SMEs. This article also focuses on competitive advantage that affects the internationalization of SMEs as mediating role between market orientation and government regulation with internationalization of SMEs within the manufacturing sector by conducting a comprehensive review of literature and via survey from CEOs of manufacturing SMEs which are located in the Klang Valley of Malaysia.

\section{Related literature review on internationalization}

The term internationalization generally covers a number of subjects and the topic has been comprehensively investigated (Benito et al., 2009; Buckley \& Casson, 2009). Internationalization is a complicated and costly process 
that requires a meticulous evaluation of opportunities, expansion through building vital infrastructures, and development and execution of multiple strategies (George et al., 2005). In this sense, internationalization can never be completely elaborated by a single theory and is better explained with an integrated combination of approaches (Chetty \& Campbell-Hunt, 2003). Therefore, the following categories represent internationalization theories and structures: the resource-Based view (RBV), the Uppsala model, the network model and OLI framework.

The resource-based view (RBV) theory points out that a firm's potential success within the market is not only reliant upon the environmental indicators but also on the function of any forms and its influence on the environment. (Barney, 1991). This theory argues that when firms follow a global strategy, they favour high control modes, especially if they possess valuable resources and capabilities (Ekeledo \& Sivakumar, 2004). Moreover, the resource-based view of the firm implies that it is the resources and capabilities within the firm that are a source of competitive advantage. The theory assumes that resources are diverse across firms and are imperfectly portable (Barney, 2001). The resource-based view demonstrates that a firm can obtain it's competitive benefit only if it gets access to some specific value resources not effortlessly imitated by any competitors. Application of such aforementioned resources as a strategic choice could result in competitive advantage as an achievement. (Hamel \& Prahalad, 1990).

The network model by Johanson \& Mattsson (1988) adopting the industrial network concept, offer a more external view to describe the internationalization of industrial firms in markets defined as "networks of relationships between firms". The network can be in the form of collaborative associations with competitors (Bernal et al., 2002) or a voluntary agreement between firms (Fuller-Love \& Thomas, 2004). It is duly recognised that a firm's internationalization involves multiple participants and therefore is not an individual effort (Mtigwe, 2006).

Johnson \& Vahlne (1977) asserted that in the Uppsala model with it the two internationalization variables of change and state dimension in which State aspect is regarded as the market knowledge and commitment while the change aspect is defined as the commitment decisions and the activities within the realm of the current business entity. . Albeit, market commitment encompasses the executed resources as well as the associate degree of engagement and it is to be noted that market knowledge assists the managerial team to make decisions accordingly. (Johnson \& Vahlne, 1990).

Dunning (1988) offered an eclectic model (also known as the OLI framework) in explaining the activities associated with foreign investment enjoying the specific ownership advantages $(\mathrm{O})$, location-specific advantages (L), and internalisation advantages (I). The first and foremost point to be mentioned, the firm must possess some ownership privilege over other firms in the host market (ownership advantage). Second, it should be beneficial for the firm to subsequently exercise command over the existing advantages instead of leasing them to other local firms (internalisation advantage). Third, the location must offer some positivities, for instance, factor inputs, which would make it desirable to the firm to locate venues outside the home country (location advantage) (Dunning, 1981).

\section{Hypothesis development}

\subsection{Hypothesis related to market orientation and internationalization}

The term Market orientation is literally regarded as the degree to which a firm involves in responsiveness, dissemination and generation to market intelligence applicable to current and future customer requirements and wants, rival strategies and measures to be taken, and broad business environment (Kohli \& Jaworski, 1990; Morgan et al., 2009). Market oriented firms adapt and implement marketing concepts. Different parts of the research community define market orientation in various ways. However, the central concept still involves generating, disseminating, sharing information, and reacting properly to changing market needs to achieve organisational goals and assure customer needs and wants while concurrently considering the interests of all company stakeholders (Wang et al., 2012).

Market orientation is an invaluable, rare, not interchangeable and imperfectly imitable, which is considered to be one of the internal capabilities and resources that can potentially bring about a sustainable competitive advantage (Hult et al., 2005; Zhou et al., 2008). The RBV can help us in understanding the nature of market orientation and its relationship with the achievement of a competitive advantage. According to this view, market orientation can be considered as a resource because it is an intangible property of a firm allowing it to supervise market information and deliver superior value to its customers (Hunt \& Lambe, 2000).

Market orientation makes the company causes the expansion and development of the new markets, such as the international markets. Knight and Cavusgil (2004) argued that the basis from which the company interrelates with various external markets is offered by market orientation. Firms with the strategic position creating particular 
market-oriented activities designed to overcome difficulties and maximize efficiency. Due to the existing lack of knowledge of the foreign worldwide marketplace, companies from developing economies endure some deficiencies, compared to their international and local competitors (Child \& Rodrigues, 2005; Luo \& Tung, 2007). These corporations need to cultivate market orientation because it offers better outcome via taking into consideration the client attitudes and the associated advantages, analysing data about competitors, and provide the necessary products and services in the right place and time.

To recapitulate,, a firm's global market orientation by itself is an idiosyncratic competence supporting the firm's activities in its markets thereby, Market orientation can be embodied as an antecedent of the internationalization process of a SME as : (1) Market orientation develops and facilitates the process of learning within foreign markets; and (2) highly market-oriented companies develop s a more robust capabilities (channel bonding, market sensing and customer linking) which allows the acqusition of foreign market knowledge, as well as designing an appropriate $\mathrm{r}$ market feedback (Armario et al., 2008).

H1a. Market orientation relates positively to the level of internationalization of manufacturing SMEs in Malaysia.

H1b. There is a positive relationship between market orientation and competitive advantage among manufacturing SMEs in Malaysia

\subsection{Hypothesis related to government regulation and internationalization}

In order to protect their citizens, governments establish regulations which aim to ensure the safety of foreign products, and to warrant sufficient levels of information about foreign products. At the same time, these regulations are used to avert the removal of substandard quality goods by exploitive foreign marketers (Cateora \& Hess, 1993). However, governments enforce unwarranted regulation to discourage foreign competition because relative to industrial markets, consumer markets are more perceptible and more susceptible (Kishore \& Kamlesh, 2008). Similarly, regional or global trade policies legalised by international agreements are outside the influence of SMEs unless a government provides an adaptable interpretation (Crick \& Chaudhry, 2000). Confusion concerning the supports and precise information is caused by discrepancies amongst the supporting government agencies and policies in certain countries e.g. Malaysia (Mahajar \& Carraher, 2006). Storey (1994) stated that complexity increases government in decisions of what and how to help the SMEs. The provision of support for SMEs seeking to internationalise is a main challenge in formulating government policy (Wright et al., 2007).

In each and every country, the government literally controls the nation and the external business environment of individual business sectors $t$ via the measures that can be broadly divided into (Kotler et al., 2002): (1) Foreign policies (2) Financial and non-financial business support provision (3) Laws and implementation of regulations, governing commercial activities. Government issues, such as regulations, export policy, procedural customs, endowments and incentives (Mtigwe, 2005; Root, 1994) also influence the internationalization process. In addition, internal issues such as tax legislation, interest rate policy, labour law regulations, and the administrative infrastructure (Boter \& Lundström, 2005) has an impact on a firm's choice. For small companies intending to internationalise, incentives, endowments, and participation in government schemes and programmes provide support and encouragement.

However, procedural customs, government trade policy, international standards and regulations can also inflict high challenges for realising foreign expansion for SMEs (Suárez-Ortega \& Álamo-Vera, 2005). Governmental laws and regulations governing the business activities, such as competition regulation laws antitrust laws, environmental requirements, etc., the aforementioned terms are not ascribable to the external business environment of elements affecting the internationalization process, for they are rather of an administrative nature, i.e. determined to standardise the businesses not directly connected to internationalization. Nonetheless, a great number of laws and rules/stipulations regulating companies or business entities, and the complexity of those regulations in nature is another issue to be taken into account, i.e. a high level of bureaucracy, can hamper business performance resulting in the external business environment factor, which is unfavourable to the internationalization issue. (Ramūnas \& Vilma, 2011). H2a. Government regulation relates positively to the level of internationalization of manufacturing SMEs in Malaysia.

$\mathrm{H} 2 \mathrm{~b}$. There is a positive relationship between Government regulation and competitive advantage among manufacturing SMEs in Malaysia.

\subsection{Competitive advantage}

According to Barney (1991), a firm possessing a competitive advantage when it executes a value creating strategy which is not concurrently being put into effect by any existing or prospective competitor; the latter is also incapable 
of replicating the benefits of this strategy. According to RBV theory firms internationalise for reasons relate to the bundle of resources that a manager uses to create value resources which are valuable, inimitable, unique and difficult to duplicate can gain competitive advantage (Wernerfelt, 1984). A firm's own capacity to efficiently exploit its own competitive advantages supporting the decision making process of penetrating into a new foreign market (Hamel \& Prahalad, 1990). According to Barney (1991).

Barney (1995) in a further refinement of his definition cited that the value, rareness and limit ability of its resources and capabilities are dependent on a firm's competitive advantage potential. In this study, competitive advantage is referred as a value creating a strategy $t$ which enables the internationalization of SMEs. The principal competitive advantage is the top management's ability to understand the process by which the knowledge-bases of SMEs are extended and altered into core competencies liberating the firm to create and control emerging opportunities (Chelliah et al., 2010).Moreover, when an organisation gains or exploits attributes and resources that permit it to surpass its competitors by offering customers a greater value, competitive advantage is said to have occurred (Huang et al., 2012).

H3a. Competitive advantage relates positively to the level of internationalization of manufacturing SMEs in Malaysia.

H3b. Competitive advantage mediates the relationship between market orientation and internationalization among manufacturing SMEs in Malaysia.

H3c. Competitive advantage mediates the relationship between Government regulation and internationalization among manufacturing SMEs in Malaysia.

From the above review of the literature and hypothesis formulation, the conceptual framework of this study is depicted in Figure 1.

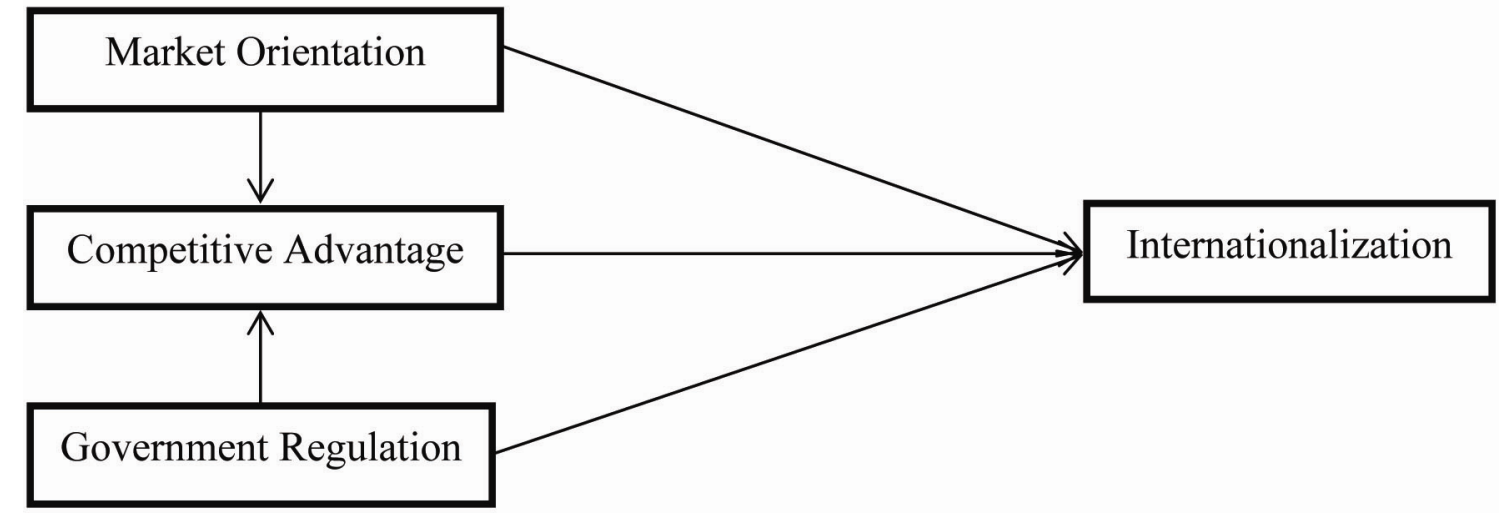

Figure 1. The conceptual framework

\section{Methodology}

\subsection{Sample and data collection}

To empirically test the developed framework, primary data were gathered using the survey questionnaire method and questioners were distributed to all manufacturing SMEs involved in exporting which are located in Klang Valley. According to FMM Directory (2012), all manufacturing SMEs involved in exporting which are located in Klang Vally is 770 and because of low response rate in Malaysian context within SMEs which is $27 \%$ (Chelliah et al., 2010), we distributed questionnaires to all companies by the researcher and his local assistant to collect the data for this study. The number of 257 questioners was used in data analysis and the response rate is $33 \%$. The response rate of this study confirms that the response rate of the survey among manufacturing SMEs is low.

\subsection{Measurement}

\subsubsection{Market orientation}

This scale was measured on fifteen items adapted from Kumar et al. (1998) and has more recently been used by Yiliu et al (2011). The response format requires that the respondent select a response among a Likert scale ranging from 1 
to 5 , where 1 demonstrates that the respondent strongly disagrees with the anchored statement, and a 5 showing that the respondent strongly agrees with the anchored statement, involving the competitor orientation, customer orientation and inter-functional coordination. The items of customer orientation are as follows: (1) we have a strong focus on client satisfaction, (2) we have a strong focus on understanding customer requirements, (3) we use the common and systematic actions of client satisfaction, (4) we pay particular attention to after-sales service, (5) we often improve customer value and reducing costs, and (6) we highlight the high quality of the products.

The items of competitor orientation are listed as follows: (1) we respond quickly to rivals' activities, (2) we share rivals' strategic data within the company, (3) top executives talk about rivals' strength and strategies are often, and (4) we have a competitive advantage in targeting clients. Inter-functional coordination consists of these items: (1) we have client data between operational services effectively, (2) we answer client calls inter-functionally, (3) all the functionality of the services contributing in putting a high value on the customer, (4) all staffs are fully aware of market data, and (5) staffs in the marketing and sales department to participate the new product development.

\subsubsection{Government regulation}

The scale of Government regulation was recognized by Pryor (2002) in four items which are: (1) the government has little or no influence on your company. (2) Senior management spends very little of its time dealing with the government. (3) Administrative regulations that constrain businesses are minimal and (4) Administrative procedures are not a serious obstacle to starting/commencing a new business. Therefore, in this study we used original items adopted from Pryor (2002) with no change and each item was measured by using a five point Likert scale ranging where 1 indicates that the respondent strongly disagrees with the anchored statement, and a 5 indicates that the respondent strongly agrees with the anchored statement.

\subsubsection{Competitive advantage}

Competitive advantage in this study was measured by Beal and Yasai (2000). It has 15-items to capture the firm's competitive advantage position along a five-point scale $(1=$ strongly disagree, $5=$ strongly agree): the variable are included: (a) innovation with 5 items: (1) R \& D of new products (2) Marketing new products (3) Selling high-priced products (4) Obtaining patents/copyrights (5) Innovative marketing techniques, (b) differentiation with 5 items: (1) Building brand/company identification (2) Advertising/promotional programs (3) Securing reliable distribution channels (4) Improvement of existing products (5) Producing broad range of products and (c) low cost leadership with 5 items: (1) Efficiency \& productivity improvements (2) New manufacturing processes (3) Improvement of existing manufacturing processes (4) Reducing costs throughout the firm (5) Reducing manufacturing costs primarily.

\subsubsection{Internationalization}

Following Zahra et al. (2000) and Zhou et al. (2007), three elements have been developed for measuring internationalization exactly for companies in emerging markets, assessing the scope of the companies' real outward actions along a five-point scale, where 1 indicates that the respondent strongly disagrees with the anchored statement, and a 5 indicates that the respondent strongly agrees with the anchored statement. $(1=$ strongly disagree, $5=$ strongly agree): (1) actively look for international markets; (2) selling products or services in international market; and (3) entry into a foreign place financed by outside FDI.

\subsection{Reliability and Construct Validity}

Reliability of the sub-measures which were developed in the present study was determined by calculating the Cronbach's Alpha value. Following Fornell and Lacker (1981), any variable with Crobach's Alpha of above 0.7 is acceptable. Construct reliability was assessed via applying the evaluation factor loading as well as considering incorporating the composite reliability and the AVE. All the constructs presented composite reliability larger than the acceptable level of 0.7 depicting that the measurement errors were quite meager. AVE values for all constructs were also larger than 0.5. Inoerder to evaluate the discriminant validity between the constructs, the test requiring the square root of AVE for each and every construct to be greater than the correlation between the two relevant latent/hidden variables was carried out. All the mentioned factors meet the discriminant criteria validity as presented in Table 1. 
Table 1. Reliability and Construct Validity Results. Legend: $\mathrm{CR}=$ Cronbac'sh Alpha, COMP $=$ Composite Reliability, $\mathrm{AVE}=$ Average Variance Extracted

\begin{tabular}{llllllll}
\hline Constructs & CR & COMP & AVE & INT & CA & GR & MO \\
\hline INT & 0.89 & 0.88 & 0.75 & 0.86 & & & \\
\hline CA & 0.92 & 0.91 & 0.54 & 0.62 & 0.76 & & \\
\hline GR & 0.86 & 0.87 & 0.61 & 0.58 & 0.49 & 0.71 & \\
\hline MO & 0.93 & 0.92 & 0.55 & 0.61 & 0.43 & 0.31 & 0.074 \\
\hline
\end{tabular}

\section{Results}

The hypotheses of this study were tested by AMOS 20. After approving the measurement model, the structural model was then examined. Six common model-fit measures were employed to assess the model's overall goodness-of-fit: the ratio of $\chi^{2}$ to degrees-of-freedom (d.f.), the comparative fit index (CFI), the Tucker-Lewis Index (TLI), the incremental fit index (IFI), the root means square residual (RMR), and the root mean square error of approximation

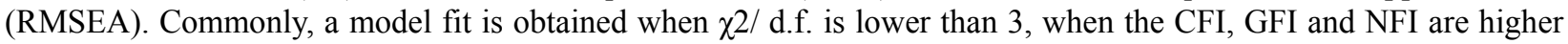
than 0.90, when RMR is lower than 0.05 and when the RMSEA is lower than 0.08 (Bemmel \& Musen, 1997). In this study, the model fit indices are: $\mathrm{RMR}=0.5, \mathrm{IFI}=0.95, \mathrm{CFI}=0.95, \mathrm{TLI}=0.95, \mathrm{RMSEA}=0.04, \chi 2 /$ d.f. $=1.4$. Obviously, these indices are within the prescribed limits and therefore, the model reflects a good fit to the data. All the hypotheses were accepted at 0.01 (Kline, 2005). The hypotheses were tested on the basis of the structural model and the outcomes are:

H1a. Market orientation relates positively to the level of internationalization of manufacturing SMEs in Malaysia ( $\mathrm{p}$-value $=0.006<0.05)$.

H1b. There is a positive relationship between market orientation and competitive advantage among manufacturing SMEs in Malaysia ( $\mathrm{p}$-value $=0.017<0.05$ ).

H2a. Government regulation relates positively to the level of internationalization of manufacturing SMEs in Malaysia (p-value $=0.003<0.05$ ).

$\mathrm{H} 2 \mathrm{~b}$. There is a positive relationship between Government regulation and competitive advantage among manufacturing SMEs in Malaysia ( $\mathrm{p}$-value $=0.004<0.05$ ).

H3a. Competitive advantage relates positively to the level of internationalization of manufacturing SMEs in Malaysia (p-value $=0.000<0.05)$.

H3b. Competitive advantage mediates the relationship between market orientation and internationalization among manufacturing SMEs in Malaysia. According to the direct model, there is a significant positive relationship between market orientation and internationalization $(\beta=0.184, p$-value $=0.006<0.05)$. Moreover, according to the full mediation model, the positive relationship between market orientation and internationalization is still significant $(\beta=$ $0.125, \mathrm{p}$-value $=0.049<0.05$ ) and also the full mediation model showed that there is a significant relationship between market orientation and competitive advantage $(\beta=0.163$, $\mathrm{p}$-value $=0.017<0.05)$. Therefore, hypothesis $\mathrm{H} 1 \mathrm{~b}$ is supported. Because $\beta$ decreased from 0.184 to 0.125 and the direct relationship between market orientation and internationalization was still significant, competitive advantage played a role of partial mediator. Therefore, hypothesis H3b is supported.

H3c. Competitive advantage mediates the relationship between Government regulation and internationalization among manufacturing SMEs in Malaysia. Based on the direct model, there is a significant positive relationship between government regulation and internationalization $(\beta=0.208, p$-value $=0.003<0.05)$. Moreover, according to the full mediation model, the positive relationship between government regulation and internationalization is still significant $(\beta=0.132, \mathrm{p}$-value $=0.053<0.05)$. Also the full mediation model shown that there is a significant relationship between government regulation and competitive advantage $(\beta=0.210, \mathrm{p}$-value $=0.004<0.05)$. Therefore, hypothesis $\mathrm{H} 2 \mathrm{~b}$ is supported. Because $\beta$ decreased from 0.208 to 0.132 and the direct relationship between government regulation and internationalization is still significant, competitive advantage played a role of partial mediator. Therefore, hypothesis $\mathrm{H} 3 \mathrm{c}$ is supported. 


\section{Discussion and conclusions}

\subsection{Managerial and theoretical implications}

Malaysia, which is regarded as an emerging market plays an undeniably paramount role in Southeast Asia and international markets. The outcomes of this research offers a number of significant research implications and managerial. From a research perspective, the findings come up with a very interesting add to the existing body of knowledge regarding the efficacy of market orientation, government regulation to internationalization and competitive advantage in explaining internationalization efforts of manufacturing SMEs in Malaysia.

The hypothesis characterizing the market orientation is positively related to the level of internationalization within manufacturing SMEs which is supported by the results of this study. A market oriented firm aims to achieve and gets access to market intelligence when it comes to the competitors, customers, technology, government, and other environmental factors in a very systematic and proactive approach. (Morgan et al., 2009). Moreover, firm with a high level of market orientation focuses on clients, competitors and internal coordination, subject to the market requirements (Narver \&Slater, 1990).

The public sector applied regulations to internationalization is also positively linked with the level of internationalization within manufacturing SMEs in Malaysia. Previously carried out studies have marked the impact of government regulatory function on internationalization of American firms (McDougall et al., 1994; Roberts \& Senturia, 1996). For small companies intending to internationalise, incentives/motivation factors, endowments, and participation in government schemes and programmes provide needed endorsement and encouragement. However, government trade policy, procedural customs, international standards and regulations as well as low level of bureaucracy can gain competitive advantage and also inflict high challenges for realising foreign expansion for SMEs (Suárez-Ortega \& Álamo-Vera, 2005).

For Malaysian SMEs, there is a strong link between competitive advantages and the level of internationalization. Once again, the finding back up previously conducted research on the interconnectedness of competitive advantage and internationalization of SMEs (Chelliah et al., 2010). When a firm is decisive to penetrate an untapped foreign market, it ought to be able to effectively exploit its own competitive advantages (Hamel \& Prahalad, 1990). Market orientation is valuable, rare, imperfectly imitable, and not interchangeable and is one of the internal resources and capabilities that can produce a sustainable competitive advantage (Hult et al., 2005; Zhou et al., 2008). Eventually, this study has assisted practitioners and managers of SMEs in Malaysian manufacturing sector to better project themselves in the improvement of their internationalization process.

\subsection{Limitation and conclusion}

Even though the firm's internationalization phenomenon interests the attention of many scholars but they allocate a little effort to understand the influential factors affecting the internationalization of SMEs, particularly SMEs in new industrialised countries and emerging markets. This study focuses on internationalization by including SMEs in emerging markets like Malaysia and also validates the findings related to internationalization which are examined in other context/settings like western countries. Therefore, this study provides an integrated framework through identification of the environmental factors based on empirical data positively influencing the internationalization growth within SMEs in Malaysia and it also, provides an opportunity for manufacturing SMEs in the development of competitive advantage through influential factors such as market orientation and government regulation in a business environment. This study enriches existing international theories because the findings of this research are usable for manufacturing SMEs in Malaysia.

Like other studies, this study suffers from some limitations. One clear limitation of the current study is the methodology of the study using a cross-sectional survey. The cross-sectional nature of this study has impeded me from achieving casual inferences from the data. A second limitation is that this study was conducted in a single country setting, Malaysia. The findings may be coloured by the culture and situational factors related to the context. As a result, caution needs to be exercised in interpreting the results in other settings. Another limitation of this study could be regarding to data collection that was such a difficult and also time consuming one to get all the questioners back. Generally, the rate of return of studies in Malaysia in this context is usually very low.

\section{References}

Ale Ebrahem, N., Shamsuddin, A., \& Zahari, T. (2010). Virtual R\&D teams and SMEs growth: A Comparative study between Iranian and Malaysian SMEs, Journal of Business Management, Volume 4 (11), page 2368- 2379.. [Online] Available: http://ssrn.com/abstract=1688934 
Armario, J.M., Ruiz, D.M., \& Armario, E.M. (2008). Market Orientation and Internationalization in Small and Medium-Sized Enterprises. Journal of Small Business Management, 46, 485-511. http://dx.doi.org/10.1111/j.1540-627X.2008.00253.x

Barney, J. (1991). Firm resources and sustained competitive advantage. Journal of Management, 17, 99-120. http://dx.doi.org/10.1177/014920639101700108

Barney, J. (1995). Looking inside for competitive advantage. The Academy of Management Executive (1993-2005), 49-61. [Online] Available: http://www.jstor.org/stable/4165714

Barney, J., Wright, M., \& Ketchen, D. (2001). The resource-based view of the firm: Ten years after 1991. Journal of Management, 27, 625-641. http://dx.doi.org/10.1177/014920630102700601

Beal, R.M., Yasai-Ardekani, M. (2000). Performance implication of aligning CEO functional experiences with competitive atrategies. Journal of Management, 26, 733-762. http://dx.doi.org/10.1177/014920630002600407

Benito, G.R.G., Petersen, B., \& Welch, L.S. (2009). Toward more realistic conceptualizations of foreign operations modes. Journal of International Business Studies, 40, 1455-70. http://dx.doi.org/10.1057/jibs.2009.54

Bernal, S.M., Burr, C., \& Johnsen, R.E. (2002). Competitor networks: international competitiveness through collaboration: The case of small freight forwarders in the High-Tech Forwarder Network. International Journal of Entrepreneurial Behaviour \& Research, 8, 239-253. http://dx.doi.org/10.1108/13552550210448348

Boter, H., \& Lundström, A. (2005). SME perspectives on business support services: The role of company size, industry and location. Journal of Small Business and Enterprise Development, 12, 244-258. http://dx.doi.org/10.1108/14626000510594638

Buckley, P.G., Casson, M.C. (2009). The internationalization theory of the multinational enterprise: a review of the progress of a research agenda after 30 years. Journal of International Business Studies, 40,1563-80. http://dx.doi.org/10.1057/jibs.2009.49

Cateora, P.R., \& Hess, J. (1993). International marketing. Homewood/IL. Boston: McGraw-Hill.

Chelliah, S., Pandian, S., Sulaiman, M., \& Munusamy, J. (2010). The moderating effect of firm size: Internationalization of small and medium enterprises (SMEs) in the manufacturing sector. African Journal of Business Management, 4, 3096-3109. [Online] Available: http://www.academicjournals.org/AJBM

Chetty, S., \& Campbell-Hunt, C. (2003). Paths to internationalisation among small-to medium-sized firms: a global versus regional approach. European Journal of Marketing, 37, 796-820. http://dx.doi.org/10.1108/03090560310465152

Child, J., \& Rodrigues, S.B. (2005). The Internationalization of Chinese Firms: A Case for Theoretical Extension?[1]. Management and Organisation Review, 1, 381-410. http://dx.doi.org/10.1111/j.1740-8784.2005.0020a.x

Crick, D., \& Chaudhry, S. (2000). UK SMEs' awareness, use, and perceptions of selected government export assistance-An investigation into the effect of ethnicity. International Journal of Entrepreneurial Behaviour \& Research, 6, 72-89. http://dx.doi.org/10.1108/13552550010335994

Dunning, J.H. (1981). International production and the multinational enterprise, Allen \& Unwin London.

Dunning, J.H. (1988). The theory of international production. International Trade Journal, 3, 21-46.

Ekeledo, I., \& Sivakumar, K. (2004). International market entry mode strategies of manufacturing firms and service firms: A resource-based perspective. International Marketing Review, 21, 68-101. http://dx.doi.org/10.1108/02651330410522943

FMM Directory. (2012). Malaysian Industries. Federation of Malaysian Manufacturers (FMM) (43th Edn.). Kuala Lumpur Malaysia.

Fornell, C., \& Lacker, D.F. (1981). Evaluating structural equation models with unobserverable variables and measurment erroe. Journal of Marketing Research, 18, 39-50. [Online] Available: http://www.jstor.org/stable/3151312

Fuller-Love, N., \& Thomas, E. (2004). Networks in small manufacturing firms. Journal of Small Business and Enterprise Development, 11, 244-253. http://dx.doi.org/10.1108/14626000410537182

George G., Wiklund J., Zahra S. A. (2005). Ownership and the Internationalization of Small Firms. Journal of Management 31, 210-233. http://dx.doi.org/10.1177/0149206304271760 
Hamel, G., \& Prahalad, C.K. (1990). The core competence of the corporation. Harvard business review, 68, 79-91.

Huang, K.C., Lu, N., Chang, W.J., Chang, H.C., \& Chen, J.S. (2012). Correlates of Perceived Competitive Advantage among Hospital Management: A Multilevel Analysis. Journal of Experimental \& Clinical Medicine, 4, 170-174. http://dx.doi.org/10.1016/j.jecm.2012.04.008

Hult, G.T.M., Ketchen, D.J., \& Slater, S.F. (2005). Market orientation and performance: an integration of disparate approaches. Strategic Management Journal, 26, 1173-1181. http://dx.doi.org/10.1002/smj.494

Hunt, S., \& Lambe, J. (2000). Marketing's Contribution to Business Strategy: Market Orientation, Relationship Marketing and Resourced-Advantage Theory. International Journal of Management Review. 2, 17-43. http://dx.doi.org/10.1111/1468-2370.00029

Ibeh, K., \& Kasem, L. (2010). The network perspective and the internationalization of small and medium sized software firms from Syria. Industrial Marketing Management, 40, 358-367. http://dx.doi.org/10.1016/j.indmarman.2010.08.004

Johanson, J., \& Mattsson, G. (1988). Internationalization in industrial systems-A Network approach. Strategies in Global Competition. New York: Croom Helm, 287-314.

Johanson, J., Vahlne, J.E. (1977). The internationalization process of the firm-a model of knowledge development and increasing foreign market commitments. Journal of International Business Studies, 23-32. [Online] Available: http://www.jstor.org/stable/254397

Johanson, J., Vahlne, J.E. (1990). The mechanism of internationalisation. International Marketing Review, 7. http://dx.doi.org/10.1108/02651339010137414

Javalgi, R., \& Todd, P. (2011). Entrepreneurial orientation, management commitment, and human capital: The internationalization of SMEs in India. Journal of Business Research, 64, 1004-1010. http://dx.doi.org/10.1016/j.jbusres.2010.11.024

Kishore, K.B., \& Kamlesh, B. (2008). The process of Internationalization in Small and Medium Enterprises (SMEs). Master's Dissertation in International marketing.

Klinel, R.B. (2005). Principles and Practice of Structural Equation Modeling. 2 ed. New York: Guilfor.

Knight, G.A, \& Cavusgil, S. (2004). Innovation, Organizational capabilities, and The Born-global Firm. Journal of International Business Studies, 35, 124-141. http://dx.doi.org/10.1057/palgrave.jibs.8400071

Kohli, A.K., \& Jaworski, B.J. (1990). Market orientation: the construct, research propositions, and managerial implications. The Journal of Marketing, 1-18. [Online] Available: http://www.jstor.org/stable/1251866

Kotler, p., Armstrong, G., Saunders, J., \& Wong, V. (2002). Principles of marketing, (3rd European ed.) - Harlow: Financial Times Prentice Hall.

Kumar, K.,Subramaniam, R.,\&Yauger, C. (1998). Examining the market orientation performance relationship Acontextspecificstudy. Journal of Management, 24, 201-233. http://dx.doi.org/ 10.1177/ 014920639802400204

Liu, Y., Li, Y., \& Xue, J. (2011). Ownership, Strategic Orientation and Internationalization in Emerging Markets. Journal of World Business, 46, 381-393. http://dx.doi.org/10.1016/j.jwb.2010.07.012

Luo, Y.D., \& Tung, R.L. (2007). International expansion of emerging market enterprises: A spring board perspective. Journal of International Business Studies, 38, 481-498. http://dx.doi.org/10.1057/palgrave.jibs.8400275

Mcdougall, P.P., Covin, J.G., Robinson, B.R., \& Herron, L. (1994). The effects of industry growth and strategic breadth on new venture performance and strategy content. Strateg Manage J, 15, 537-54. http://dx.doi.org/10.1002/smj.4250150704

Mahajar, A.j., \& Carraher, S.M. (2006). The effectiveness of SMIDEC in Malaysia at assisting SMEs at exporting. Conference proceeding at the Academy for Global Business Advancement Third World Congress. January 4-6,2006,KualaLumpur,Malaysia. http://www.agba.us/AGBA_2006_ConferenceProceedings.pdf.

Majocchi, A., Bacchiocchi, E., \& Mayrhofer, U. (2005). Firm size, business experience and export intensity in SMEs: A longitudinal approach to complex relationships. International Business Review, 14, 719-738. http://dx.doi.org/10.1016/j.ibusrev.2005.07.004 
Masca, E. (2012). Influence of Cultural Factors in Adoption of the IFRS for SMEs. Procedia Economics and Finance, 3, 567-575. http://dx.doi.org/10.1016/S2212-5671(12)00197-9

Morgan, N.A., Vorhies, D.W., \& Mason, C.H. (2009). Market orientation, marketing capabilities, and firm performance. Strategic Management Journal, 30, 909-920. http://dx.doi.org/10.1002/smj.764

Mtigwe, B. (2005). The entrepreneurial firm internationalization process in the Southern African context: A comparative approach. International Journal of Entrepreneurial Behaviour \& Research, 11, 358-377. http://dx.doi.org/10.1108/13552550510615006

Mtigwe, B. (2006). Theoretical milestones in international business: The journey to international entrepreneurship theory. Journal of International Entrepreneurship, 4, 5-25. http://dx.doi.org/10.1007/s10843-006-5872-5

Narver, J.C., \& Slater, S.F. (1990). The effect of a market orientation on business profitability. Journal of Marketing Research, 54, 20. [Online] Available: http://www.jstor.org/stable/1251757

Pryor-Frederic, L. (2002). QuantitativeNotes on the Extent of Governmental Regulations in Various OECD Nations. International Journal of Industrial Organization, 20, 693-714. http://dx.doi.org/10.1016/S0167-7187(00)00115-6

Ramūnas, Č., \& Vilma, D. (2011). Impact of external business environment factors on internationalization of lithuanian born global companies. ekonomoka., 90.

Roberts, E.B., \& Senturia, A. (1996). Globalizing the emerging high-technology company. Industrial Marketing Management, 25, 491-506. http://dx.doi.org/10.1016/S0019-8501(96)00072-7

Root, F.R. (1994). Entry Strategy for International Markets. Toronto Lexington Books, Maxwell. McMillan, Canada.

Storey, D.J. (1994). Understanding the small business sector, Thomson Learning Emea.

Suárez-Ortega, S.m., \& Álamo-Vera, F.R. (2005). SMES'internationalization: firms and managerial factors. International Journal of Entrepreneurial Behaviour \& Research, 11, 258-279. http://dx.doi.org/10.1108/13552550510603298

Wang, C.H., Chen, K.Y., \& Chen, S.C. (2012). Total quality management, market orientation and hotel performance: The moderating effects of external environmental factors. International Journal of Hospitality Management. http://dx.doi.org/10.1016/j.ijhm.2011.03.013

Wernerfelt, B. (1984). A resource-based view of the firm. Strategic Management Journal. 5, 171-180. http://dx.doi.org/10.1002/smj.4250050207

Wright, M., Westhead, P., \& Ucbasaran, D. (2007). Internationalization of small and medium-sized enterprises (SMEs) and international entrepreneurship: a critique and policy implications. Regional Studies, 41, 1013-http://dx.doi.org/1030.10.1080/00343400601120288

Zahra, S.A., Neubaum, D.O., \& Huse.M. (2000). Entrepreneurship in medium-size companies: Exploring the effects of ownership and governance systems. Journal of Management, 26, 947-976. http://dx.doi.org/10.1177/014920630002600509

Zhou, K.Z., Li, J.J., Zhou, N., \& Su, C. (2008). Market orientation, job satisfaction, product quality, and firm performance: evidence from China. Strategic Management Journal, 29, 985-1000. http://dx.doi.org/10.1002/smj.700

Zhou, L.X., Wu,W.P., \& Luo,X.M. (2007). Internationalization and the performance of born global SMEs:The mediating role of social networks. Journal of International Business Studies, 38, 673-690. http://dx.doi.org10.1057/palgrave.jibs.8400282 